\title{
Aplikasi Smartphone GIS (Geografik Information System) Pencarian Sekolah SMK Daerah Cirebon Berbasis Android
}

\author{
Sari Noorlima Yanti ${ }^{1}$, Endah Budiyati ${ }^{2}$, Esti Setiyaningsih ${ }^{3}$ \\ Fakultas Teknik Industri, Universitas Gunadarma \\ e-mail: 1'sariny@ staff.gunadarma.ac.id, ${ }^{2}$ endah_b@staff.gunadarma.ac.id, \\ 3esti@staff.gunadarma.ac.id
}

Submitted Date: January $13^{\text {th }}, 2020$

Revised Date: January $28^{\text {th }}, 2020$
Reviewed Date: January $14^{\text {th }}, 2020$

Accepted Date: January $31^{\text {st }}, 2020$

\begin{abstract}
GIS application is an Android-based application that contains information about the user's location and user address located. The problem of finding information about the existence of a school location with the help of maps on internet facilities. The method of finding information with the GIS contained in this application includes a map as well as the location of Vocational High Schools in the Cirebon Region. Other information includes the address, telephone number and directions from the user's location to the destination school. This application is created using the Action Script programming language and the software uses Eclipse. Android is an operating system platform that is open or opensource. Android-based java programming language code that is multiplatform. Java-based application developers can freely build applications openly that can run on many Android-based devices. The results of this study are to provide information to Android device users about the location of Vocational Schools in the Cirebon Region.
\end{abstract}

Keywords: GIS, Vocational School, Cirebon

Abstrak

Aplikasi GIS yaitu aplikasi yang berbasis Android yang berisi tentang informasi lokasi user dan alamat user berada. Permasalahan pencarian informasi tentang keberadaan suatu lokasi sekolah dengan bantuan peta pada fasilitas internet. Metode pencarian informasi dengan GIS yang terdapat di dalam aplikasi ini memuat peta juga lokasi Sekolah Menengah Kejuruan di Daerah Cirebon. Informasi lain terdapat alamat, nomor telepon serta dilengkapi direction dari lokasi pengguna ke Sekolah yang dituju. Aplikasi ini dibuat dengan menggunakan bahasa pemrograman Action Script dan software-nya menggunakan Eclipse. Android adalah platform operating System yang terbuka atau opensource. Kode bahasa pemrograman android berbasis java yang bersifat multiplatform. Para pengembang aplikasi berbasis java secara bebas bisa membangun aplikasi secara terbuka yang dapat berjalan di banyak perangkat berbasis android. Hasil Penelitian ini adalah untuk memberikan informasi kepada pengguna perangkat Android mengenai lokasi Sekolah Tingkat SMK yang berada di Daerah Cirebon.

Kata Kunci: GIS, Sekolah SMK, Cirebon

\section{Pendahuluan}

Cirebon merupakan salah satu daerah berkembang yang ada di Propinsi Jawa Barat. Untuk itu, kebutuhan informasi tentang fasilitas umum di Daerah Cirebon semakin tinggi. Daerah Cirebon memiliki berbagai macam informasi yang berhubungan dengan lokasi geografisnya, seperti informasi jalan dan lokasi suatu fasilitas umum antara lain Sekolah, tempat wisata, tempat ibadah dan lain sebagainya. Tentunya informasi tersebut sangat dibutuhkan oleh berbagai pihak dengan berbagai keperluannya masing-masing.

Salah satu informasi yang dibutuhkan adalah informasi mengenai Sekolah Menengah Kejuruan yang ada di Daerah Cirebon. Informasi tersebut dapat berupa alamat, nomer telepon dan peta dari SMK tersebut. Dengan berbagai informasi tersebut mampu memberikan bantuan kepada masyarakat Daerah Cirebon dan masyarakat dari luar daerah yang akan menyekolahkan anaknya di SMK yang ada di Daerah Cirebon. 
Dengan berkembangnya ilmu pengetahuan dan teknologi saat ini terutama pada sistem informasi. Kini masyarakat dapat mengetahui letak dan informasi suatu wilayah dengan cepat dan mudah melalui perangkat mobile yang memiliki sistem operasi Android. Salah satunya dengan adanya peta virtual pada perangkat mobile berbasis Android, kini masyarakat dapat dengan cepat mengetahui lokasi dari tempat yang dituju.

Penelitian ini mengembangkan konsepkonsep Location Based Service (LBS) sebagai penyedia dan pemroses informasi berdasarkan lokasi mengenai informasi yang berkaitan dengan Sekolah yang ada di Daerah Cirebon. Informasi yang ada, antara lain: alamat, nomor telepon dan peta. Aplikasi ini juga menerapkan fitur GPS dalam perangkat Android. (Prahasta, Eddy, 2005) Aplikasi pencarian Sekolah di Daerah Cirebon ini menggunakan android. Dalam Penelitiannya Peneliti menggunakan Unified Modeling Language (UML) Use Case Diagram.

\section{Landasan Teori}

\subsection{Pemrograman Java di Eclipse Android}

Eclipse merupakan sebuah IDE (Integrated

Development Environment) untuk mengembangkan perangkat lunak yang dapat dijalankan disemua platform (platformindependent).

Android merupakan suatu sistem operasi berbasis Linux dipergunakan untuk telepon seluler seperti telepon pintar atau komputer tablet. Android adalah aplikasi platform terbuka utuk para pengembang dalam menciptakan aplikasi mereka dan digunakan dengan bermacam peranti bergerak. Awalnya, Google Inc. membeli Android Inc. pendatang baru yang membuat peranti lunak perangkat bergerak. Perkembangan Aplikasi Android lebih lanjut maka dibentuklah Open Handset Alliance, yaoitu suatu konsorsium terdiri dari tiga puluh empat perusahaan hardware, software, dan telekomunikasi, termasuk didalamnya adalah Google, HTC, Qualcomm, Motorola, T-Mobile, Intel, dan Nvidia. (N. Safaat, 2015)

\subsection{Google Maps}

Google Maps berisi peta yang ada di dunia dan dapat digunakan untuk melihat suatu daerah. Google Maps merupakan suatu peta yang dapat dilihat dengan menggunakan suatu browser. Fitur Google Maps dapat kita tambahkan kedalam web yang kita buat. Google Map juga dapat kita masukan kedalam blog kita yang berbayar maupun gratis sekalipun. (M. Syaiful Amri, 2014) . Berikut ini adalah peta pada Google Map:

- ROADMAP, ini yang saya pilih, untuk menampilkan peta biasa 2 dimensi.

- $\quad$ SATELLITE, untuk menampilkan foto satelit.

- TERRAIN, untuk menunjukkan relief fisik permukaan bumi dan menunjukkan seberapa tingginya suatu lokasi, contohnya akan menunjukkan gunung dan sungai.

- HYBRID, menunjukkan foto satelit yang diatasnya tergambar seperti yangtampil pada ROADMAP (jalan dan nama kota).

\subsection{Google API}

Google API adalah kode program yang disederhanakan untuk kita tambahkan ke sebuah aplikasi atau web yang kita bangun. Kode API ini dapat dipergunakan untuk mengakses, menjalankan, memanfaatkan fungsi atau fitur yang ada pada Google. Misalnya saja kita bisa menambahkan fitur Google Map pada website kita. Google API dapat dipelajari langsung melalui Google Code. Pada fungsi Google Code kita belajar tentang Google API kemudian dapat mengimplementasikan pada aplikasi website yang kita kembangkan. (Rena Ariyanti, Khairil, Indra Kanedi, 2015)

Berikut ini adalah sebagian kode API yang terdapat pada Google, beberapa diantaranya adalah:

1. Language API fungsi untuk memanfaatkan fitur translation Google.

2. Earth API untuk memanfatkan fitur Google Earth

3. Javascript API

4. Maps API memanfaatkan fitur Google Maps

5. Search API fitur untuk memanfaatkan pencarian Google Search

6. Visualization API berfungsi membuat grafik atau chart Google API

7. YouTube API digunakan untuk memanfaatkan fitur YouTube.

\subsection{UML (Unified Modeling Language)}

UML merupakan perangkat bahasa logika dan menjadi standar dalam industri untuk visualisasi, merancang dan mendokumentasikan sistem perangkat lunak. UML merupakan sebuah bahasa standar untuk merancang model dari sistem. Bahasa UML seperti bahasa lainnya mendefinisikan notasi dan sintaks atau semantik. Terdapat 3 Notasi UML yang diturunkan dari perangkat Ivar Jacobson OOSE (Object-Oriented Software Engineering), Jim Rumbaugh OMT (Object Modeling Technique), dan Grady Booch 
OOD (Object-Oriented Design). (A. Nugroho, 2010)

\subsection{Use Case Diagram}

Use Case diagram adalah diagram fungsionalitas dari sebuah sistem. Usecase diagram menekankan "apa" yang diperbuat sistem, dan bukan "bagaimana". Suatu Use Case menjelaskan suatu interaksi antara aktor dengan sistem. Diagram Use Case menjelaskan sebuah pekerjaan tertentu. Contoh pekerjaannya seperti login ke sistem, membuat sebuah daftar belanja dan sebagainya. Aktor menjelaskan sebuah entitas manusia atau mesin yang dapat berinteraksi dengan sistem dan melakukan proses pekerjaan. (A. Nugroho, 2010).

\subsection{Struktur Navigasi}

Struktur navigasi merupakan alur suatu program menjelaskan rancangan hubungan kerja dari beberapa bagian yang berbeda. Menentukan struktur navigasi merupakan hal yang sebaiknya dilakukan sebelum membuat suatu aplikasi, karena hal itu menentukan sekaligus menjadi patokan dalam membuat aplikasi. Struktur Navigasi adalah struktur bagaimana halaman web dihubungkan dengan halaman lain. (Sutopo, Ariesto Hadi. 2017). Ada empat macam bentuk dasar dari struktur navigasi yang biasa digunakan, yaitu Linier, Non Linier, Hierarchy dan Composite. (Luther-Sutopo, 2003)

\section{Metode Penelitian}

Dalam penelitian ini, peneliti menggunakan metode penelitian dengan tahapan sebagai berikut:

1. Tahapan Analisis Data. Dalam pengumpulan data, metode yang digunakan adalah metode pustaka, di mana peneliti menggunakan fasilitas internet untuk mencari bahan-bahan yang dapat dijadikan referensi serta buku-buku yang berhubungan dengan perancangan aplikasi peta elektronik.

2. Tahapan Perancangan. Peneliti mendesain antarmuka aplikasi yang dapat ditampilkan dalam aplikasi LBS Sekolah tingkat SMK di Daerah sehingga maksud dan tujuan dari pembuatan aplikasi ini dapat terpenuhi sesuai dengan kebutuhan pemakai. Dalam tahap ini peneliti menggunakan spesifikasi perangkat keras dan perangkat lunak sebagai berikut: Sebuah Komputer dengan spesifikasi Intel Core ${ }^{\mathrm{TM}}$ i3-2350M, memory 8 GB DDR3 dan kapasitas harddisk 500 GB. Android SDK r24.0.2 for windows 64 bit. Flash Cs6 for windows 64 bit. Smartphone Asus Zenfone 5 (A500CG), RAM 2 GB.

3. Tahapan Pengujian Aplikasi pada program yang telah dibuat dan dicermati dengan seksama apakah masih ada kekurangan didalam aplikasi tersebut.

4. Tahapan pembutan dengan menggunakan bahasa pemrograman pemrograman java android dengan menggunakan editor Eclipse.

\section{Hasil Dan Pembahasan}

Tahapan yang dilakukan untuk mendukung pembuatan aplikasi ini dengan membuat struktur navigasi, storyboard, perancangan interface, implementasi, spesifikasi software dan hardware. Aplikasi ini dirancang untuk memberikan informasi kepada masyarakat serta lokasi Sekolah SMK yang ada di Daerah Cirebon dengan bantuan google maps.

Perangcangan Aplikasi merupakan tahapan dari rancangan program yang akan dilakukan. Pertama adalah merancang diagram UML(Unified Modelling Language). Diagram UML adalah Use Case Diagram

\subsection{Perancangan Aplikasi}

Dalam Penelitian ini, Peneliti membuat sebuah aplikasi mobile yang menampilkan informasi berupa tampilan peta lokasi SMK yang ada di Daerah Cirebon yang dapat dijalankan pada Smarthphone yang memiliki sistem operasi Android. Pada tampilan utama terdapat menu Lokasi, Lokasi Sekolah, About dan Exit.

Pada saat pertama kali aplikasi di jalankan maka yang pertama kali muncul adalah halaman loading, lalu akan masuk kedalam menu utama dimana pada menu tersebut terdapat empat button yaitu Lokasi, Lokasi Sekolah, About dan Exit.

Button Lokasi menampilkan lokasi user dan alamat dimana sekarang kita berada. Button Lokasi Sekolah menampilkan lokasi Sekolah yang ada di Daerah Cirebon dan menampilkan lokasi user pada saat ini.

Button Help and About menampilkan layout yang berisi tentang keterangan singkat dari Peneliti dan cara penggunaan aplikasi.

Button Exit menampilkan Alert Dialog yang berisi pertanyaan keluar dari aplikasi.

\subsection{Struktur Navigasi}

Pada struktur navigasi ini yang digunakan adalah struktur navigasi hirarki. Karena dalam aplikasi ini terdapat sebuah halaman loading dan menu utama yang berisi menu-menu lainnya. 
Gambar 1 merupakan gambar struktur navigasi dari aplikasi LBS SMK di Daerah Cirebon.

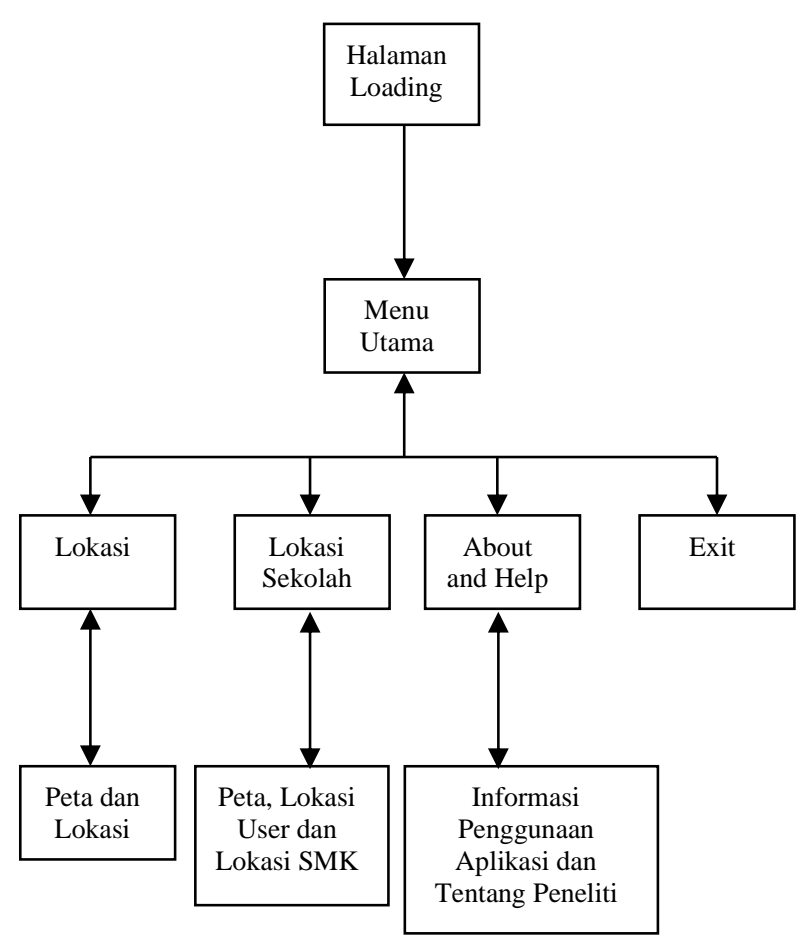

Gambar 1 Struktur Navigasi

\subsection{Flowchart}

Berikut ini Peneliti akan membuat flowchart dari aplikasi LBS SMK di Daerah Cirebon.

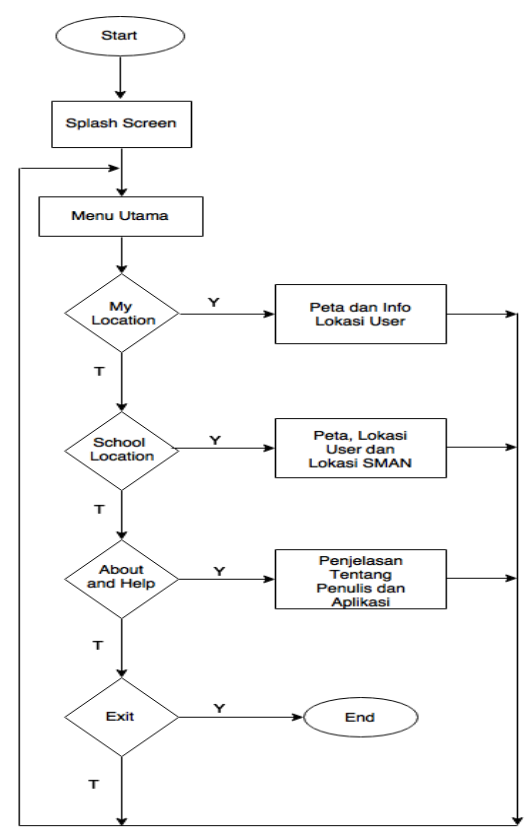

Gambar 2 Flowchart Aplikasi
Pada saat aplikasi dijalankan yang pertama kali dimunculkan oleh program adalah halaman loading setelah itu langsung ke halaman menu utama, kemudian ada empat kondisi.

Kondisi yang pertama yaitu apakah button Lokasi dipilih oleh user, jika ya maka aplikasi menampilkan peta lokasi dan alamat dimana user berada, jika tidak maka diperiksa kondisi yang kedua.

Kondisi kedua yaitu apakah button Lokasi Sekolah dipilih oleh user, jika ya maka aplikasi menampilkan peta, lokasi user, lokasi SMK dan direction ke SMK yang dituju, jika tidak maka diperiksa kondisi yang ketiga.

Kondisi ketiga yaitu apakah button About and Help dipilih oleh user, jika ya maka aplikasi menampilkan halaman cara pengguanaan aplikasi dan tentang Peneliti, jika tidak maka diperiksa kondisi yang keempat.

Kondisi yang keempat yaitu apakah button Exit dipilih oleh user, jika ya maka aplikasi selesai, jika tidak maka aplikasi menampilkan menu utama.

\subsection{Pembuatan Storyboard}

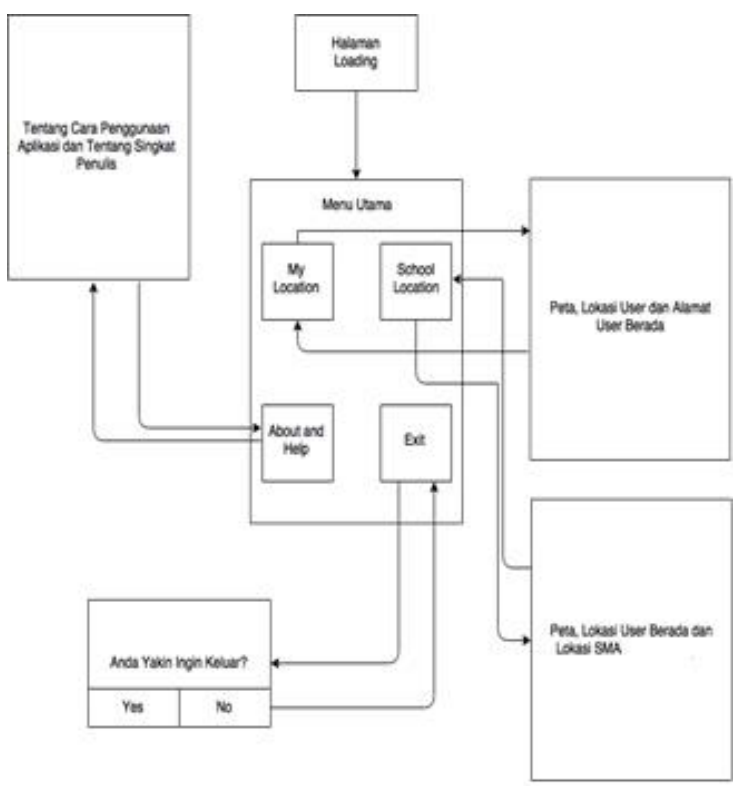

Gambar 3. Storyboard

Storyboard pada gambar diatas menjelaskan tentang alur program untuk mengakses halaman yang satu dengan halaman yang lainnya. Saat aplikasi pertama kali dijalankan, halaman loading yang pertama kali muncul, lalu menampilkan menu utama. Didalam menu utama terdapat empat buah button, yaitu Lokasi, Lokasi Sekolah, About and Help dan Exit. Button Lokasi menampilkan tampilan peta, lokasi dan alamat dari user berada. 
Button Lokasi Sekolah menampilan tampilan peta, lokasi user dan lokasi Sekolah .

\subsection{Perancangan Model Sistem}

Dalam perancangan aplikasi perlu adanya pemodelan, pemodelan dibuat menggunakan diagram UML sebagai visualiasasi model dari sistem aplikasi LBS SMK di Daerah Cirebon. Pengguna menjadi aktor yang mengakses pada aplikasi LBS SMK di Daerah Cirebon ini. Dalam perancangan aplikasi ini menggunakan Use Case Diagram.

Use Case merupakan skenario (serangkaian langkah yang menggambarkan interaksi antar user dan system) yang terikat bersama oleh suatu tujuan yang sama dengan pengguna. Use Case menggambarkan pola perilaku software aplikasi, termasuk adanya urutan interaksi antar aktor dengan software aplikasi tersebut.

Use Case digunakan untuk menunjukan hubungan (relationship) antar aktor sebagai pengguna system dengan Use Case yang digunakan.

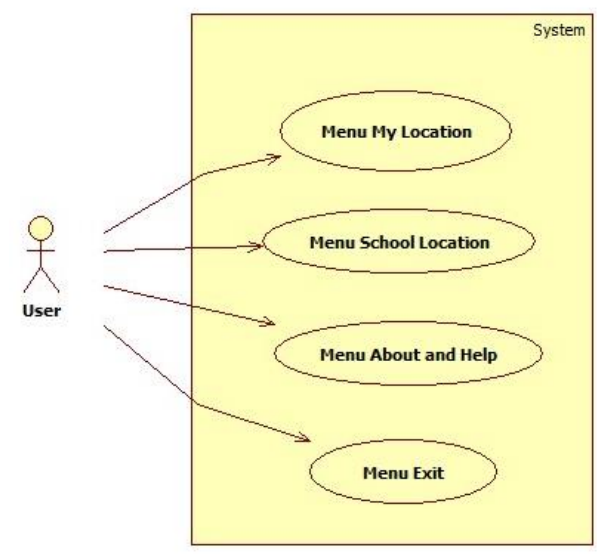

Gambar 4 Use Case Diagram

\subsection{Rancangan Tampilan}

Rancangan tampilan merupakan tahap yang sangat berperan penting dalam pembuatan aplikasi. Proses rancangan aplikasi dibutuhkan arsitektur aplikasi dan juga kemudahan dalam menggunakan aplikasi tersebut.

Halaman yang pertama kali tampil ketika user menggunakan aplikasi LBS SMK di Daerah Cirebon. Terdapat sebuah gambar imageview dan progress bar. Rancangan tampilan halaman Splash Screen terdapat pada gambar 5 .

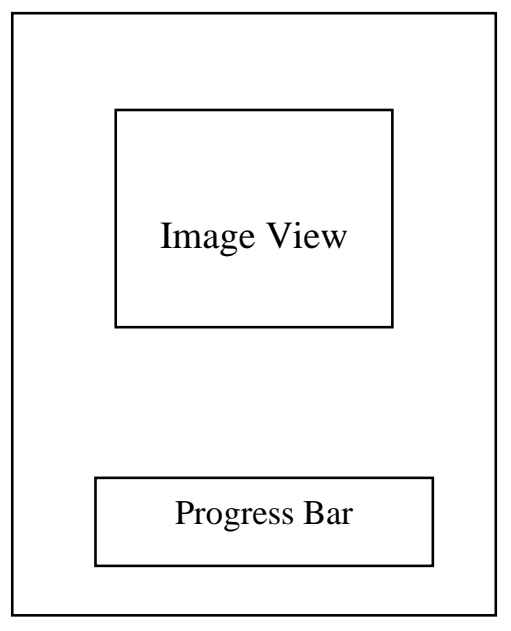

Gambar 5 Rancangan Splash Screen

\subsection{Rancangan Tampilan Menu Utama}

Pada halaman ini menampilkan menu utama yang ada di dalam aplikasi LBS SMK di Daerah Cirebon. Di dalam halaman ini terdapat empat buah textview dan empat buah image button yang dapat digunakan, yaitu Image Button1 yang digunakan untuk masuk ke dalam tampilan Lokasi. Image Button2 yang digunakan untuk masuk ke dalam tampilan Lokasi Sekolah. Image Button3 yang digunakan untuk masuk kedalam tampilan cara penggunaan aplikasi dan keterangan Peneliti. Image Button4 yang digunakan untuk keluar dari aplikasi ini sedangkan textview digunakan untuk pemberian nama button.

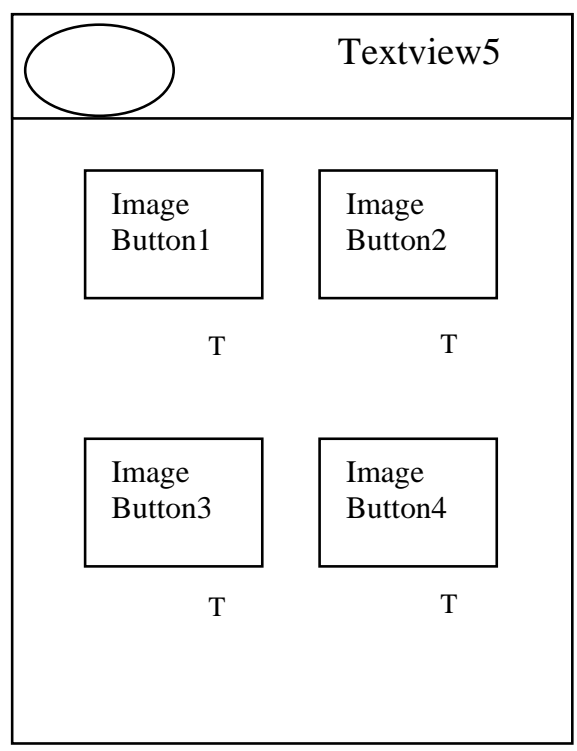

Gambar 6 Rancangan Menu Utama

Keterangan:

- Logo : merupakan icon dari aplikasi

- Textview5 : merupakan judul aplikasi 
- Image Button1: tombol Lokasi untuk masuk kedalam tampilan peta dan alamat lokasi user.

- Image Button2: tombol Lokasi Sekolah untuk masuk kedalam tampilan peta, lokasi SMK di Daerah Cirebon dan lokasi user.

- Image Button3: tombol About and Help untuk menampilkan layout tentang Peneliti dan cara penggunaan aplikasi.

- Image Button4: tombol Exit digunakan untuk keluar dari aplikasi.

\subsection{Rancangan Tampilan Lokasi}

Halaman ini tampil pada saat pengguna memilih button Lokasi. Pada halaman ini terdapat judul halaman aplikasi, peta, lokasi user berada dan alamat user berada. Rancangan tampilan ini dijelaskan pada gambar 7 di bawah ini.

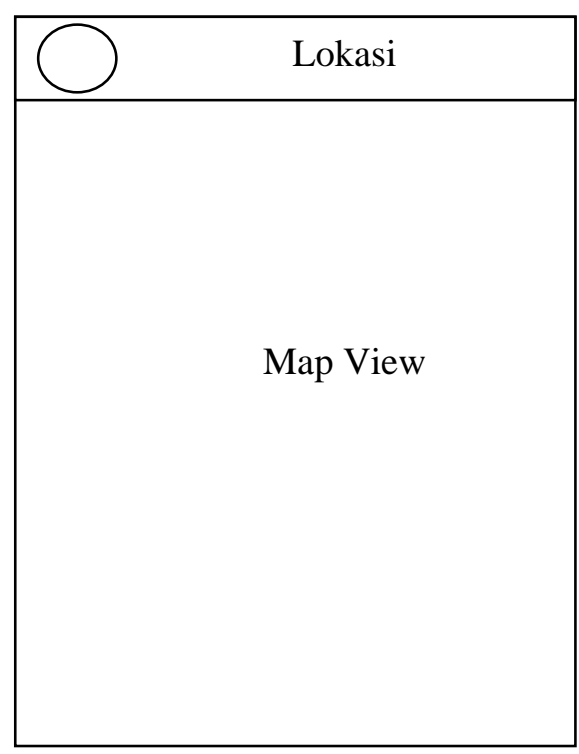

Gambar 7 Rancangan Lokasi

Keterangan:

- Map View: tampilan isi peta untuk lokasi user berada.

\subsection{Rancangan Tampilan Lokasi Sekolah}

Halaman Lokasi Sekolah berisi tentang informasi peta, letak user dan seluruh lokasi SMK yang ada di Daerah Cirebon. Rancangan tampilan ini dijelaskan pada gambar 8 dibawah ini.

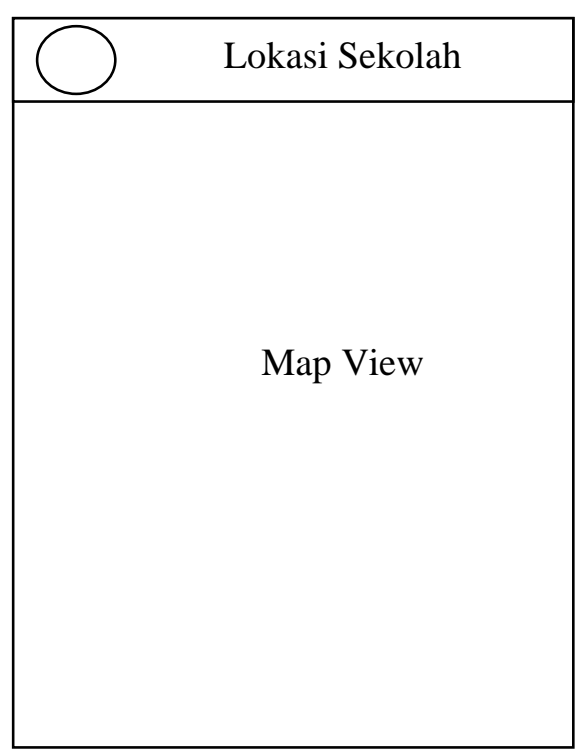

Gambar 8 Rancangan Lokasi Sekolah

Keterangan:

- Map View : tampilan isi peta untuk lokasi user berada dan lokasi SMK di Daerah Cirebon.

\subsection{Langkah Pembuatan Aplikasi}

Langkah pembuatan aplikasi merupakan langkah selanjutnya setelah kita merancang tampilan dari aplikasi tersebut. Langkah pembuatan aplikasi merupakan langkah untuk menerapkan semua rancangan dalam alur yang telah dibuat kedalam barisan program yang terstruktur. Dalam pembuatan aplikasi ini dibutuhkan beberapa software pendukung yang harus di install ke dalam komputer Peneliti. Software tersebut adalah JDK jdk1.7.0_07 dan Jre 7, Android SDK Manager, Eclipse Kepler dan aplikasi emulator ini biasa disebut AVD atau Android Visual Device.

Setelah semua langkah diatas selesai dilakukan, maka langkah berikutnya adalah membuat project baru. Pilih toolbar menu file, pilih new, kemudian klik Android Application Project. Langkah berikutnya adalah membuat source code dari aplikasi LBS SMK di Daerah Cirebon.

\subsection{Uji Coba Aplikasi}

Tahap ini merupakan tahap akhir dari pembuatan aplikasi ini dengan melakukan pengujian pada device Android Kitkat versi 4.4.2 dengan layar 5.0 inch. Berikut ini adalah tampilan loading dari aplikasi ini pada gambar 11. 


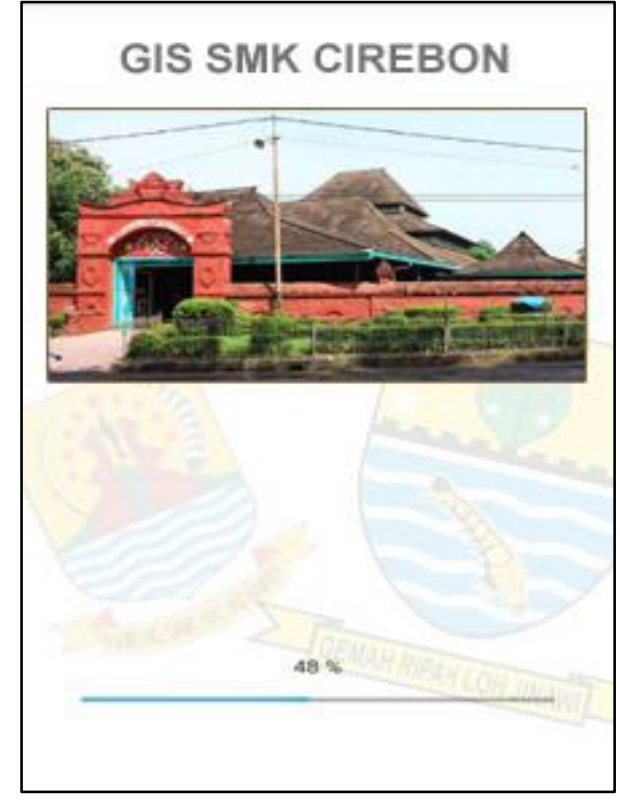

Gambar. 11 Tampilan Splash Screen

Tampilan splash screen merupakan tampilan awal pada saat aplikasi dijalankan. Setelah itu aplikasi masuk kedalam menu utama yang merupakan menu awal dari aplikasi LBS SMK di Daerah Cirebon.

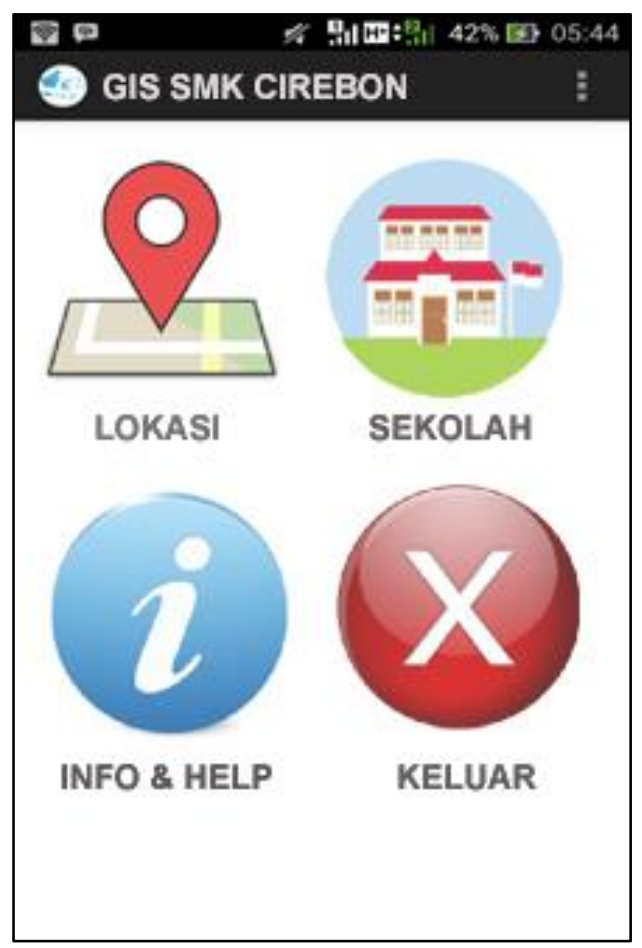

Gambar 12 Tampilan Menu Utama

Tampilan menu utama dari aplikasi. Di halaman ini terdapat beberapa pilihan menu. Lokasi untuk masuk ke tampilan peta pengguna berada. Lokasi Sekolah untuk masuk ke tampilan peta lokasi SMK di Daerah Cirebon dan lokasi pengguna.

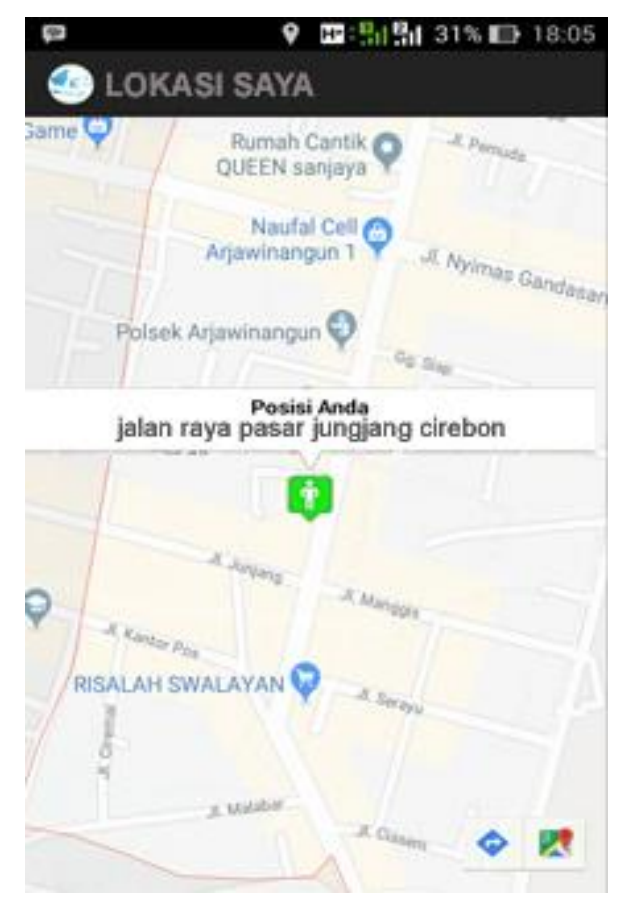

Gambar 13 Tampilan Menu Lokasi

Gambar 13 merupakan tampilan ketika memilih button Lokasi. Di halaman ini terdapat maps yang menampilkan lokasi pengguna dengan alamat secara lengkap.

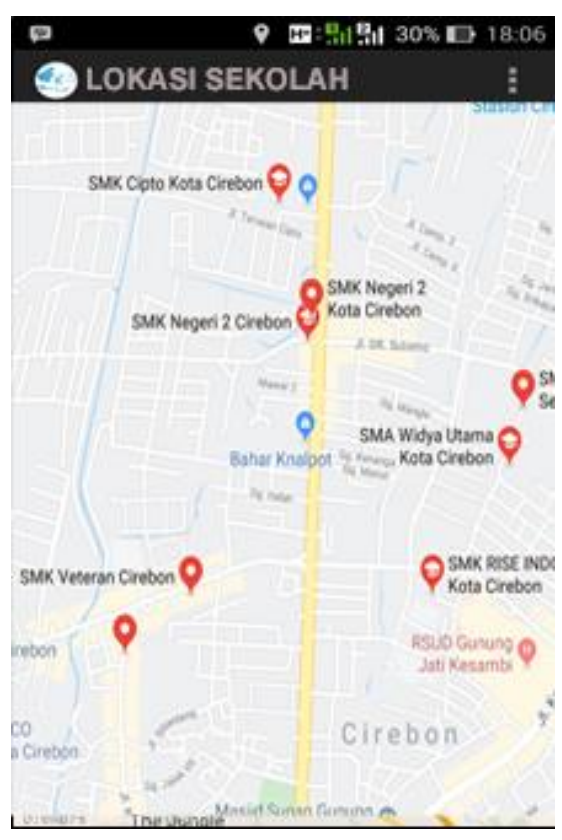

Gambar 14 Tampilan Lokasi Sekolah 
Gambar 14 merupakan tampilan dari ketika memilih menu Lokasi Sekolah. Di halaman ini terdapat maps, lokasi pengguna dan lokasi SMK yang ada di Daerah Cirebon.

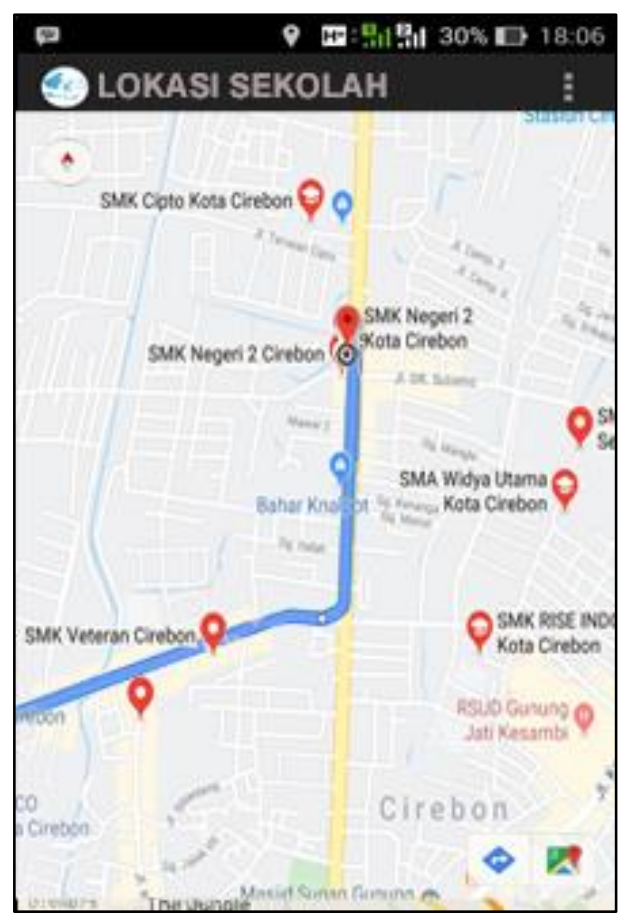

Gambar 15 Tampilan Rute Lokasi Sekolah

Pada gambar 15 merupakan tampilan menu Lokasi Sekolah ketika alamat Sekolah di klik. Klik pada marker info alamat SMK maka jalur untuk menuju SMK tersebut akan terlihat dari posisi pengguna berada.

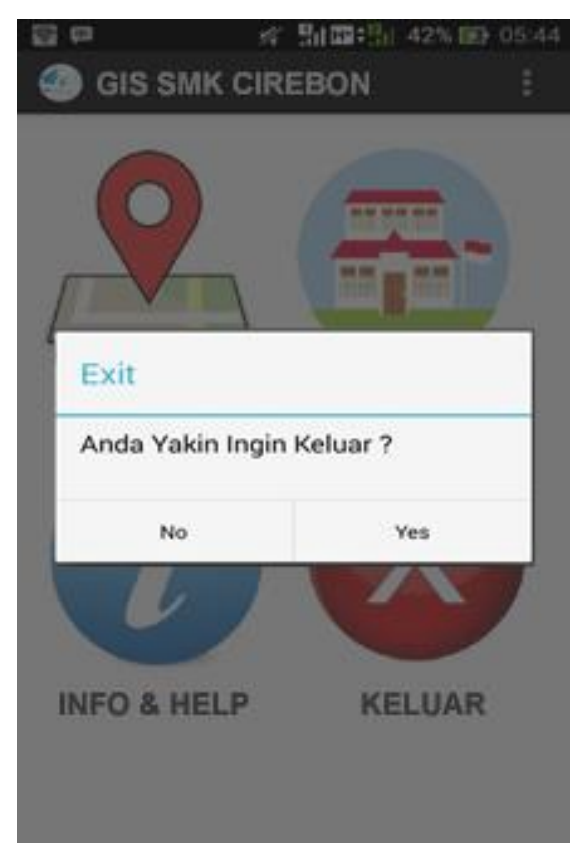

\section{Gambar 16 Tampilan Dialog Keluar}

Gambar 16 merupakan tampilan dialog keluar dari aplikasi ini. Ketika pengguna memilih 'Yes' maka aplikasi berhenti, jika memilih 'No' maka aplikasi tetap berjalan.

\section{Kesimpulan}

Aplikasi GIS SMK di Daerah Cirebon berbasis Android telah selesai dibuat dan diterapkan pada Smartphone. Kesulitan yang dialami dalam membuat aplikasi ini adalah dalam membuat maps, dibutuhkan ketelitian dalam menghubungkan titik kordinatdengan maps.

Aplikasi ini mempunyai kelebihan selain mencari lokasi sekolah yaitu menampilkan secara detail informasi sekolah. Informasi yang di dapat oleh pengguna yaitu alamat, nomor telpon.

Hasil uji coba yang telah diterapkan pada beberapa Smartphone android dapat disimpulkan proses aplikasi berjalan baik pada Smartphone Samsung Galaxy S7 Edge dengan versi sistem operasi 7.0, android Asus Zenfone 5 dengan versi sistem operasi 4.4.2, android Samsung Galaxy Grand Duos dengan versi sistem operasi 4.4.2, android Vivo Y555 dengan versi sistem operasi 6.0. Aplikasi ini juga memiliki kekurangan di mana di dalam aplikasi ini user interface hanya mencakup 1 wilayah saja, serta pengembangannya terhadap platform lain seperti IOS.

\section{Referensi}

N. Safaat, 2015, "Pemograman Aplikasi Mobile Smartphone Dan Tablet PC Berbasis Android", Bandung, Informatika.

Rena Ariyanti, Khairil, Indra Kanedi, Jurnal Media Infotama Vol. 11 No. 2, September 2015 ISSN 1858 - 2680 Pemanfaatan Google Maps Api Pada Sistem Informasi Geografis Direktori Perguruan Tinggi Di Kota Bengkulu.

A. Nugroho, Rekayasa Perangkat Lunak Menggunakan Uml Dan Java, Andi, 2010.

Sutopo, Ariesto Hadi. Pemrograman Flash Dengan PHP dan MySQL, Yogyakarta, Graha ilmu, 2007

Luther-Sutopo (2003). Multimedia Interaktif dengan Flash. Graha Ilmu. Yogyakarta.

Prahasta, Eddy. 2005. Konsep-Konsep Dasar Sistem Informasi Geografis. Bandung: Informatika

M. Syaiful Amri, Tahun 2014 "Membangun Sistem Navigasi di Surabaya Menggunakan Google Map Api" Jurnal Politeknik Elektronikan Negeri Surabaya. 